P ISSN : 2503 - 1708

E ISSN : 2722 - 7340

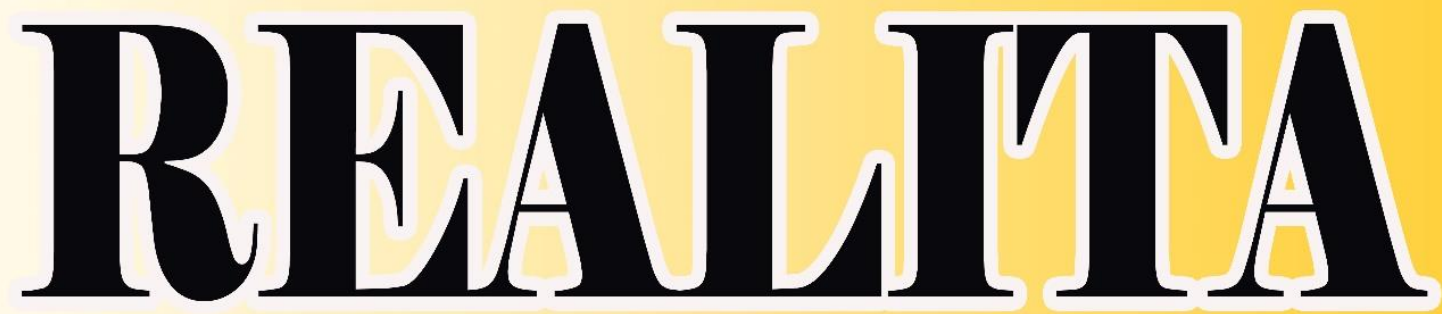

Jurnal Bimbingan dan Konseling

\begin{tabular}{|c|c|c|c|c|c|}
\hline JURNAL & VOLUME & NOMOR & EDISI & HALAMAN & P ISSN : 2503 - 1708 \\
REALITA & 6 & 2 & Oktober 2021 & $1326-1430$ & E ISSN : 2722 - 7340 \\
\hline
\end{tabular}

Diterbitkan oleh:

PROGRAM STUDI BIMBINGAN DAN KONSELING FAKULTAS ILMU PENDIDIKAN DAN PSIKOLOGI UNIVERSITAS PENDIDIKAN MANDALIKA 


\section{REALITA \\ BIMBINGAN DAN KONSELING \\ Jurnal Penelitian dan Pengembangan Pendidikan}

\section{DEWAN REDAKASI \\ Pelindung : Rektor Universitas Pendidikan Mandalika \\ : Dekan FIPP Universitas Pendidikan Mandalika \\ Penanggung \\ Jawab \\ : Kaprodi BK FIPP Universitas Pendidikan Mandalika \\ Editor}

Hariadi Ahmad, M.Pd

Universitas Pendidikan Mandalika

Associate Editor

Mustakim, M.Pd

Universitas Pendidikan Mandalika

Mujiburrahman, M.Pd

Universitas Pendidikan Mandalika

Ahmad Muzanni, M.Pd

Universitas Pendidikan Mandalika

M. Chaerul Anam, M.Pd

Universitas Pendidikan Mandalika

\section{Editorial Board}

Prof. Drs. Kusno, DEA., Ph.D

Universitas Negeri Jember Jawa Timur

Drs. Wayan Tamba, M.Pd

Farida Herna Astuti, M.Pd

Ichwanul Mustakim, M.Pd

Reza Zulaifi, M.Pd

Jessica Festi Maharani, M.Pd

Universitas Pendidikan Mandalika

Universitas Pendidikan Mandalika

Universitas Pendidikan Mandalika

Universitas Pendidikan Mandalika

Universitas Pendidikan Mandalika

\section{Reviwer}

Dr. I Made Sonny Gunawan, S.Pd., M.Pd

Universitas Pendidikan Mandalika

Dr. A. Hari Witono, M.Pd

Universitas Mataram NTB

Prof. Dr. Wayan Maba

Universitas Mahasaraswati Bali

Dr. Gunawan, M.Pd

Universitas Mataram NTB

Dr. Haromain, S.Pd., M.Pd.

Universitas Pendidikan Mandalika

Dr. Hadi Gunawan Sakti, M.Pd

Wiryo Nuryono, M.Pd

Hasrul, S.PdI., M.Pd

Dita Kurnia Sari, M.Pd

Dr. Roro Umy Badriyah. M.Pd., Kons

Universitas Pendidikan Mandalika

Universitas Negeri Surabaya Jawa Timur

STKIP Kie Raha Ternate Maluku Utara

UIN Sunan Ampel Surabaya Jawa Timur

Universitas PGRI Maha Dewa Bali

Ari Khusumadewi, M.Pd

Universitas Negeri Surabaya Jawa Timur 
M. Najamuddin, M.Pd

M. Samsul Hadi, M.Pd

Lalu Jaswandi, M.Pd

Eneng Garnika, M.Pd

Aluh Hartati, M.Pd

Drs. I Made Gunawan, M.Pd

Nuraeni, S.Pd., M.Si

Baiq Sarlita Kartiani, M.Pd

M. Zainuddin, M.Pd

Ahmad Zainul Irfan, M.Pd

Dra. Ni Ketut Alit Suarti, M.Pd

Asep Sahrudin, S.Pd., M.Pd

Suciati Rahayu Widyastuti, S.Pd., M.Pd

Rahmawati M, S.Pd., M.Pd

Ginanjar Nugraheningsih, S.Pd. Jas., M.Or

Dewi Ariani, S.Pd., M.Pd

St. Muriati, S.Pd., M.Pd

Uli Agustina Gultom, S.Pd., M.Pd

Indra Zultiar, S.Pd., M.Pd.
Universitas Pendidikan Mandalika

Universitas Pendidikan Mandalika

Universitas Pendidikan Mandalika

Universitas Pendidikan Mandalika

Universitas Pendidikan Mandalika

Universitas Pendidikan Mandalika

Universitas Pendidikan Mandalika

Universitas Pendidikan Mandalika

Universitas Pendidikan Mandalika

Universitas Pendidikan Mandalika

Universitas Pendidikan Mandalika

Univ. Mathla'ul Anwar Banten

Univ. Nahdlatul Ulama Cirebon

Universitas Muhammadiyah Kendari Sulawesi Tenggara

Universitas Mercu Buana Yogyakarta

Universitas Mahaputra Muhammad Yamin Solok Sumatera Barat

Universitas Bosowa Makassar Sulawesi Selatan

Universitas Borneo Tarakan Kalimantan Utara

Universitas Muhammadiyah Sukabumi Jawa Barat

\section{Alamat Redaksi:}

Redaksi Jurnal Realita Bimbingan dan Konseling (JRbk)

Program Studi Bimbingan dan Konseling

Fakultas Ilmu Pendidikan dan Psikologi Universitas Pendidikan Mandalika

Gedung Dwitiya, Lt. 3 Jalan Pemuda No. 59 A Mataram Telp. (0370) 638991

Email : realita@undikma.ac.id

Web : e-journal.undikma.ac.id

Jurnal Realita Bimbingan dan Konseling menerima naskah tulisan penulis yang original (belum pernah diterbitkan sebelumnya) dalam bentuk soft file, office word document (Email) atau Submission lansung di akun yang diterbitkan setiap bulan April dan Oktober setiap tahun.

Diterbitkan Oleh: Program Studi Bimbingan dan Konseling Fakultas Ilmu Pendidikan dan Psikologi Universitas Pendidikan Mandalika. 


\section{DAFTAR ISI}

Halaman

\section{Nuraeni dan Mastari}

Pengaruh Konseling Kelompok Terhadap Self Esteem Siswa Kelas XI di SMK Negeri 2 Kuripan

\section{Aprilia Yolanda, Ni Ketut Alit Suarti dan Ahmad Muzanni}

Pengaruh Body Shaming Terhadap Kepercayaan Diri Siswa SMA Negeri

1 Batulayar

$1342-1353$

\section{Hariadi Ahmad}

Hubungan Kestabilan Emosi dengan Kontrol Diri Siswa Sekolah Menegah Pertama

\section{Aluh Hartati}

Pengaruh Teknik Modeling Untuk Meningkatkan Empati Siswa

\section{Mustakim}

Pengaruh Teknik Cerita Terhadap Sikap Kemandirian Anak Pada Usia 5-6 Tahun

\section{Farida Herna Astuti dan Ichwanul Mustakim}

Keefektifan Bimbingan Kelompok dengan Teknik Role Playing untuk Meningkatkan Motivasi Belajar

\section{Mujiburrahman dan Soba Al-Qadri}

Hubungan Antara Kemampuan Kontrol Diri Dengan Penyusaian Diri Pada Siswa Kelas XI SMA Negeri 1 Taliwang

\section{Wiwiek Zainar Sri Utami}

Pengaruh Konseling Individu Terhadap Potensi Diri Anak Tunarungu di Sekolah Inklusi

\section{Baiq Nur'aini Cahya Khairani dan Ni Made Sulastri}

Pengaruh Layanan Konseling Humanistik Terhadap Perilaku Agresif pada Siswa Kelas XI IPS-4 di SMA Negeri 7 Mataram

\section{Najamudin}

Pengaruh Teknik Biblioterapi Terhadap Sikap Kemandirian Belajar Pada Siswa VIII SMP Negeri 5 Lembar

\section{Khaerul Huda}

Meningkatkan Pengetahuan dan Pemahaman Perilaku Hidup Bersih dan Sehat dimasa Covid 19 Melalui Metode Demontrasi pada Kelompok B di TK Negeri 01 Wanasaba 


\title{
PENGARUH TEKNIK CERITA TERHADAP SIKAP KEMANDIRIAN ANAK PADA USIA 5-6 TAHUN
}

\author{
Oleh: \\ Mustakim \\ Dosen Program Studi Bimbingan dan Konseling Fakultas Ilmu Pendidikan dan \\ Psikologi Universitas Pendidikan Mandalika \\ Email: mustakim@ikipmataram.ac.id
}

\begin{abstract}
Abstrak. Bermain merupakan dunia anak, dengan bermain anak mendapatkan stimulus yang tepat, dan memahami kehidupan. Sehingga aspek perkembangan anak dapat tercapai. Rumusan masalah dalam penelitian ini adalah apakah ada pengaruh teknik cerita terhadap sikap kemandirian anak usia 5-6 tahun? Sedangkan tujuan dari penelitian ini adalah untuk mengetahui pengaruh teknik cerita terhadap sikap kemandirian anak usia 5-6 tahun. Metode pengumpulan data yang digunakan dalam penelitian ini adalah metode observasi sebagai metode utama, pengamatan, metode dokumentasi dan wawancara sebagai pelengkap. Sedangkan metode analisa data yang digunakan dalam penelitian ini adalah metode analisis statistik dengan rumus t-tes. Berdasarkan hasil analisis data bahwa t hitung yang diperoleh adalah sebesar 7,678 sedangkan nilai t-tabel $(7,678>2,145)$. Hal ini berarti Ho ditolak sedangkan Ha diterima. Kesimpulan yang diperoleh dalam penelitian ini adalah ada pengaruh teknik cerita terhadap sikap kemandirian anak usia 5-6 tahun, artinya hasil penelitian pengaruh teknik cerita terhadap sikap kemandirian anak usia 5-6 tahun "signifikan".
\end{abstract}

\section{Kata Kunci: Teknik Cerita, Sikap Kemandirian}

\section{PENDAHULUAN}

Kita semua menyadari bahwa pendidikan merupakan salah satu proses yang wajib diberikan pada anak sebagai proses pengubahan karakter anak dan perilaku anak melaui upaya bimbingan dan pembelajaran. Bimbingan sangat erat hubungannya dengan prilaku anak, karena anak merupakan titik pusat proses bimbingan belajar mengajar. Oleh karena itu, dalam meningkatkan pendidikan harus diikuti dengan peningkatan mutu anak. Peningkatan mutu anak dapat dilihat pada tingginya tingkat prestasi belajar anak, sedangkan tingginya tingkat prestasi belajar anak dipengaruhi oleh sikap kemandirian anak itu sendiri (Hariadi A, Aluh H, dan Nuraeni. 2018). Pendidikan mempunyai peran yang sangat penting dalam meningkatkan karakteristik anak, sebab melalui pendidikan diharapkan dapat menghasilkan generasi penerus yang berkualitas. Pendidikan merupakan usaha dasar dan terencana untuk dapat mewujudkan suasana belajar dan proses Pembelajaran agar peserta didik secara aktif mengembangkan potensi dirinya untuk memiliki kekuatan spiritual keagamaan, pengendalian diri, kepribadian, akhlak mulia, mandiri, serta ketrampilan yang diperlukan dirinya, masyarakat dan bangsa (UU No 20 Tahun 2003).

Sikap kemandirian anak merupakan salah satu unsur yang penting dalam Pembelajaran. Sikap kemandirian menekankan pada aktivitas anak dalam belajar yang penuh tanggung jawab atas keberhasilan dalam belajar. Anak yang memiliki sikap kemandirian yang kuat tidak akan mudah menyerah. Sikap kemandirian dapat ditunjukkan dengan adanya kemampuan menyelesaikan masalah yang dihadapi dengan tingkah laku (Hariadi A, Aluh H dan Jessica FM. 2020). Dengan adanya perubahan tingkahlaku, maka anak juga memiliki 
peningkatan dalam berfikir, menganggap bahwa dalam belajar harus bisa mandiri tanpa mengandalkan bantuan dari orang lain, dan juga tidak menggantungkan belajar dari guru saja, tapi belajar juga bisa dari, alam atau yang lainnya (Hariadi A, Ahmad ZI dan Dedi A. 2020).

Kepribadian seorang anak yang memiliki ciri kemandirian berpengaruh positif terhadap prestasi belajarnya. Hal ini bisa terjadi karena anak mulai dengan kepercayaan terhadap kemampuannya sendiri secara sadar, teratur dan disiplin berusaha dengan sungguh-sungguh untuk mengejar prestasi belajar, mereka tidak merasa rendah diri dan siap mengatasi masalah yang muncul. Menurut Barnadib (dalam Fatimah, 2010) kemandirian meliputi perilaku mampu berinisiatif, mampu mengatasi hambatan/masalah, mempunyai rasa percaya diri dan dapat melakukan sesuatu sendiri tanpa bantuan orang lain. Di lembaga sekolah, mereka dilatih dan dibina secara mental dan fisik agar menjadi pribadi yang siap berdikari (berdiri di atas kaki sendiri) pada masa depan dan tentunya diimbangi dengan bekal ilmu pengetahuan dan ketrampilan yang dapat diandalkan untuk membuktikan bahwa anak didik tersebut memiliki potensi (Hariadi A dan Dini K. 2017). Sikap kemandirian sangat diperlukan, karena kemandirian merupakan proses menggerakkan kekuatan atau dorongan dari dalam diri individu yang belajar untuk menggerakkan potensi dalam dirinya tanpa ada tekanan atau pengaruh asing dari luar dirinya. Oleh karena itu, guru punya peran besar dalam miningkatkan sikap kemandirian dalam belajar pada anak. Dari berbagai teknik yang ada, Teknik cerita dipilih peneliti untuk membantu meningkatkan sikap kemandirian anak, cerita yang akan peneliti gunakan adalah cerita rakyat atau cerita local (Hariadi A dan Aluh $\mathrm{H}$.
2016).

Sehingga dalam setiap tingkah lakunya tidak banyak menggantungkan diri pada orang lain, biasanya pada orang tuanya. Anak yang kurang mandiri selalu ingin ditemani atau ditunggui oleh orang tuanya, baik pada saat sekolah maupun pada saat bermain. Kemana-mana harus ditemani orang tua atau saudaranya. Berbeda dengan anak yang memiliki kemandiran, ia berani memutuskan pilihannya sendiri, tingkat kepercayaan dirinya lebih nampak, dan mudah menyesuaikan diri dengan lingkungan dan teman bermain maupun orang asing yang baru dikenalnya (Hariadi A dan Aluh H. 2016).

\section{KAJIAN PUSTAKA}

Kemandirian (self reliance) adalah kemampuan untuk mengelola semua yang dimiliki, tahu bagaimana mengelola waktu, berjalan dan berpikir secara mandiri disertai dengan kemampuan mengambil resiko dan memecahkan masalah. Individu yang mandiri tidak membutuhkan petunjuk yang detail dan terus menerus tentang bagaimana mencapai produk akhir, ia bisa bersandar pada diri sendiri. Kemandirian berkenaan dengan tugas dan keterampilan bagaimana mengerjakan sesuatu mencapai sesuatu dan bagaimana mengelola sesuatu (Parker, 2005).

Kemandirian dapat diartikan sebagai usaha seseorang untuk mempertahankan kelangsungan hidupnya dengan melepaskan diri dari orangtua atau orang dewasa untuk mengerjakan sesuatu atas dorongan diri sendiri dan kepercayaan diri tanpa adanya pengaruh dari lingkungan dan ketergantungan pada orang lain, adanya kebebasan mengambil inisiatif untuk mengatur kebutuhan sendiri, dan mampu memecahkan persoalan dan hambatan yang dihadapi tanpa bantuan orang lain (Aluh $\mathrm{H}$, Hariadi A dan RM. 2020). Kemampuan 
demikian hanya mungkin dimiliki jika seseorang berkemampuan memikirkan dengan seksama tentang sesuatu yang dikerjakan atau diputuskannya,

Ada beberapa aspek dalam kemandirian pada anak seperti yang dijelaskan Martin (2000), yaitu: a). Selfregulation Anak mampu menyesuaikan tingkah laku agar sesuai dengan apa yang mereka ketahui dapat diterima oleh lingkungan sosialnya. Anak berusaha menghindari tingkah laku-tingkah laku yang menurut pengalamannya tidak harus dan tidak patut dilakukan. Tingkah lakutingkah laku yang menjadi indikator adanya self-regulation di antaranya dapat memasukkan makanan ke dalam mulut dengan benar, dapat menggunakan alat makan/minum dengan benar, membuang sampah pada tempatnya, mau merapikan mainan ke tempat semula, makan dengan rapi, mau bersalaman dengan orang baru, makan dan minum pada waktu yang ditetapkan, mau menghabiskan makanan atau memberitahukan kalau sudah kenyang, mau mengikuti permainan denganteman-teman dan mematuhi peraturan yang ada, tidak meminta bantuan terus-menerus, mau tidur sendiri, tidak menangis saat ditinggal, dan mau meminjamkan mainan pada temannya (Hariadi A, dan Yolana O. 2019).

Self-control Anak mengendalikan tingkah lakunya sesuai dengan tuntuan sosial yaitu jenis perilaku yang disenangi oleh orang tua di rumah atau guru di sekolah. Tingkah laku-tingkah laku yang menjadi indikator adanya self-control di antaranya bisa duduk atau jongkok di WC dengan posisi yang benar, tidak mengompol, dan tidak merengek saat menyampaikan sesuatu. Self-efficacy Anak memiliki perasaan mampu mengerjakan sendiri sesuatu secara efektif. Tingkah laku-tingkah laku yang menjadi indikator adanya selfdetermination di antaranya mau membereskan mainan tanpa disuruh, mengambil gelasnya sendiri dengan satu tangan, mencoba menyisir rambut sendiri, mencoba memakai atau melepaskan pakaian sendiri, mencoba memakai atau melepaskan kaus kaki atau sepatu sendiri, menggosok gigi sendiri tanpa dibantu, menolak bantuan yangditawarkan apabila merasa mampu. Self-determination Anak mampu menentukan sendiri apa yang ingin atau akan dilakukannya. Tingkah laku-tingkah laku yang menjadi indikator adanya self determination di antaranya bisa memilih baju yang akan dipakai, memilih mainannya sendiri, dan mampu menentukan makanan atau hal lain kesukaannya (Hariadi A, Mustakim dan Syafaruddin. 2018).

Sejak usia dini anak sudah mulai dibiasakan untuk dapat mandiri mengurus dirinya dimulai dari hal-hal yang ringan, seperti mencuci tangan, menyisir rambut, mandi, memakai baju sendiri dan sebagainya (Hasrul dan Hariadi A. 2021). Metode Pembelajaran yang dilakukan adalah: Metode Penguatan Kelompok (Group Reinforcement) Penguatan kelompok merupakan referensi yang diberikan oleh kelompoknya (peer) khususnya pada anak usia dini. Jenis fererensi ini penting karena mereka sangat mengacu kepada kelompok sebaya (peers). Metode ini pada umumnya digunakan untuk menjelaskan kepada anak yang ikut belajar terstruktur tentang apa yang hendak dicapai. Cara Pembelajaran ulang (reinstruction) dapat digunakan pula untuk memperjelas perilaku apa yang akan dibentuk. Penguatan kelompok dapat dilakukan dengan menggunakan pemodelan (modeling) yaitu memberikan contoh perilaku apa yang diharapkan atau dengan perkataan lain belajar melalui imitasi (peniruan) (Hariadi A dan Aluh H. 2016).

Kegiatan Pembelajaran yang dilakukan dengan menanamkan 
pembiasaan pada anak. Pembiasaan merupakan proses Pembelajaran yang paling tepat bagi anak usia dini karena terjadi proses pembentukan sikap dan perilaku yang relatif menetap dan bersifat otomatis karena dilakukan berulangulang. Dalam pembiasaan tidak memerlukan fungsi berpikir yang cukup tinggi, misalnya untuk dapat mengucapkan salam anak cukup menggunakan fungsi berpikir dengan mengingat atau meniru saja. Dalam pembiasaan bukan hasil proses kematangan tetapi sebagai akibat dari hasil pengalaman atau belajar. Untuk menanamkan pembiasaan terhadap anak usia Kelompok Bermain, yaitu usia 2-3 tahun sebaiknya dilakukan secara fleksibel dan dapat dilaksanakan secara rutin, spontan dan terprogram (Hariadi A dan Aluh H. 2016).

Proses imitasi adalah proses peniruan terhadap tingkah laku sikap serta cara pandang orang dewasa (model) dalam aktivitas yang dilihat anak. Proses identifikasi merupakan proses terjadinya pengaruh sosial pada seseorang yang didasarkan pada orang tersebut untuk menjadi seperti individu lain yang dikaguminya. Atau dengan perkataan lain proses menjadi menyamakan tingah laku sosial orang yang berada disekitarnya sesuai dengan perannya kelak di masyarakat. Proses internalisasi berupa proses penanaman serta penyerapan nilainilai. Atau relatif mantap dan menetapnya suatu nilai-nilai sosial pada diri seseorang sehingga nilai-nilai tersebut tertanam dan menjadi milik orang tersebut (Hariadi A dan Aluh $\mathrm{H}$. 2016).

Anak yang mandiri adalah anak yang memiliki kepercayaan diri dan motivasi yang tinggi. Sehingga dalam setiap tingkah lakunya tidak banyak menggantungkan diri pada orang lain, biasanya pada orang tuanya. Anak yang kurang mandiri selalu ingin ditemani atau ditunggui oleh orang tuanya, baik pada saat sekolah maupun pada saat bermain. Kemana-mana harus ditemani orang tua atau saudaranya. Berbeda dengan anak yang memiliki kemandiran, ia berani memutuskan pilihannya sendiri, tingkat kepercayaan dirinya lebih nampak, dan mudah menyesuaikan diri dengan lingkungan dan teman bermain maupun orang asing yang baru dikenalnya.

Menurut Zimmerman yang dikutif oleh Tillman dan Weiss (2000) anak yang mandiri itu adalah anak yang mempunyai kepercayaan diri dan motivasi instrinsik yang tinggi. Zimmerman yakin bahwa kepercayaan diri dan motivasi instrinsik tersebut merupakan kunci utama bagi kemandirian anak. Dengan kepercayaan dirinya, anak berani tampil dan berekspresi di depan orang banyak atau di depan umum. Penampilannya tidak terlihat malu-malu, kaku, atau canggung, tapi ia mampu beraksi dengan wajar dan bahkan mengesankan. Sementara, motivasi instrinsik, atau motivasi bawaan, dapat membawa anak untuk berkembang lebih cepat, terutama perkembangan otak atau kognitifnya. Anak yang memiliki motivasi tinggi ini dapat terlihat dari perilakunya yang aktif, kreatif, dan memiliki sifat ingin tahu (curiositas) yang tinggi. Anak tersebut biasanya selalu banyak bertanya dan serba ingin tahu, selalu mencobanya, mempraktekkannya, dan mencoba-coba sesuatu yang baru.

Sedangkan menurut Puntrich (1999) anak mandiri itu adalah anak yang mampu menggabungkan motivasi dan kognitifnya sekaligus, sehinggga dapat dikatakan bahwa menjadi anak yang mandiri tergantung pada kepercayaan terhadap diri sendiri dan motivasinya. Pada aspek motivasi, anak yang mandiri, biasanya ditandai dengan kemauannya yang keras, tidak cepat putus asa, bahkan tidak cepat bosan sebelum ia mampu 
mengetahui dan mencapai sesuatu yang dicarinya. Sementara pada aspek kognitif, anak telah memiliki banyak pengetahuan dan perbendaharaan kata atau kalimat yang diutarakannya. Dengan segenap pengetahuan dan perbendaharaan kata tersebut, maka akan memuculkan sikap mandiri dan keberanian yang tinggi, baik dalam sikap dan perbuatannya, maupun dalam menetapkan keputusan yang diambilnya.

Selain itu, kemandirian anak juga sangat dipengaruhi oleh perlakuan orang tua atau saudara-saudaranya dalam keluarga.Anak yang selalu diawasi secara ketat, banyak dicegah atau selalu dilarang dalam setiap aktivitasnya dapat berakibat patahnya kemandirian seseorang.Sikap yang bijak dan perlakuan yang wajar pada anak dapat memicu tumbuhnya kemandirian anak.Orang tua yang terlalu protektif pada anaknya, terlalu ketat pengawasannya, banyak dicegah, dengan alasan takut kotor, takut merusak, atau kekhawatiran terjadi kecelakaan, pada akhirnya bisa berakibat fatal. Alih-alih bermaksud untuk melindungi atau menjaga anak dari kecelakaan, kebersihan, dan kerusakan, malah membuat anak menjadi penakut, kurang percaya diri, serta serba ketergantungan pada orang lain.

Sikap yang wajar dan tidak berlebihan yang perlu dilakukan oleh orang tua terhadap anaknya adalah sebagaimana yang dikemukakan oleh Sylvia Rimm (2003). Dengan meramu dari beberapa pendapat di atas, dapat dipahami bahwa ciri-ciri kemandirian anak, termasuk juga pada anak usia dini, adalah sebagai berikut: (1). Kepercayaan pada diri sendiri. Rasa percaya diri, atau dalam kalangan anak muda biasa disebut dengan istilah 'PD'ini sengaja ditempatkan sebagai ciri pertama dari sifat kemandirian anak, karena memang rasa percaya diri ini memegang peran penting bagi seseorang, termasuk anak usia dini, dalam bersikap dan bertingkah laku atau dalam beraktivitas sehari-hari.Anak yang memiliki kepercayaan diri lebih berani untuk melakukan sesuatu, menentukan pilihan sesuai dengan kehendaknya sendiri dan bertanggung jawab terhadap konsekwensi yang ditimbulkan karena pilihannya. Kepercayaan diri sangat terkait dengan kemandirian anak. Dalam kasus tertentu, anak yang memiliki percaya diri yang tinggi dapat menutupi kekurangan dan kebodohan yang melekat pada dirinya. Oleh karena itu, dalam berbagai kesempatan, sikap percaya diri perlu ditanamkan dan dipupuk sejak awal pada anak usia dini ini. (2). Motivasi instrinsik yang tinggi. Motivasi instrinsik adalah dorongan yang tumbuh dalam diri untuk melakukan sesuatu. Motivasi instrinsik biasanya lebih kuat dan abadi dibandingkan dengan motivasi ekstrinsik walupun kedua motivasi ini kadang berkurnag, tapi kadang juga bertambah. Kekuatan yang datang dari dalam akan mampu menggerakkan untuk melakukan sesuatu yang diinginkan. Keingintahuan seseorang yang murni adalah merupakan salah satu contoh motivsasi instrinsik. Dengan adanya keingintahuan yang mendalam ini dapat mendorong seseorang untuk melakukan sesuatu yang memungkinkan ia memperoleh apa yang dicita-citakannya. Dengan keinginan dan tekad yang kuat, orang biasanya menjadi lupa waktu, keadaan, dan bahkan lupa diri sendiri. (3) Mampu dan berani menentukan pilihan sendiri. Anak mandiri memiliki kemampuan dan keberanian dalam menentukan pilihan sendiri. Misalnya dalam memilih alat bermain atau alat belajar yang akan digunakannya. (4). Kreatif dan inovatif. Kreatif dan inovatif pada anak usia dini merupakan ciri anak yang memiliki kemandirian, seperti dalam melakukan sesuatu atas kehendak sendiri tanpa disuruh oleh orang lain, tidak 
ketergantungan kepada orang lain dalam melakukan sesuatu, meyukai pada hal-hal baru yang semula dia belum tahu, dan selalu ingin mencoba hal-hal yang baru. (5). Bertanggung jawab menerima konsekwensi yang menyertai pilihannya. Di dalam mengambil keputuan atau pilihan tentu ada konsekwensi yang melekat pada pilihannya. Anak yang mandiri dia bertanggung jawab atas keputusan yang diambilnya apapun yang terjadi tentu saja bagi anak Taman Kanak-kanak tanggung jawab pada taraf yang wajar. Misalnya tidak menangis ketika ia salah mengambil alat mainan, dengan senang hati mengganti dengan alat mainan yang lain yang diinginkannya. (6). Menyesuiaiakan diri dengan lingkungannya. Lingkungan sekolah (Taman Kanak-kanak) merupakan lingkungan baru bagi anakanak. Sering dijumpai anak menangis ketika pertama masuk sekolah karena mereka merasa asing dengan lingkungan di Taman Kanak-kanak bahkan tidak sedikit yang ingin ditunggui oleh orang tuanya ketika anak sedang belajar. Namun, bagi anak yang memiliki kemandirian, dia akan cepat menyesuaiakan diri degan lingkungan yang baru. (7). Tidak ketergantungan kepada orang lain. Anak mandiri selalu ingin mencoba sendiri-sendiri dalam melakukan sesuatu tidak bergantung pada orang lain dan anak tahu kapan waktunya meminta bantuan orang lain, setelah anak berusaha melakukannya sendiri tetapi tidak mampu untuk mendapatkannya, baru anak meminta bantuan orang lain. Seperti mengambil alat mainan yang berada di tempat yang tidak terjangkau oleh anak.

Cerita merupakan cerita yang berasal dari masyarakat dan berkembang dalam masyarakat pada masa lampau yang menjadi ciri khas disetiap bangsa yang mempunyai kultur budaya yang beraneka ragam yang mencakup kekayaan budaya dan sejarah yang dimiliki masing-masing bangsa. Pada umumnya cerita rakyat ini mengisahkan mengenai suatu kejadian di suatu tempat atau asal muasal suatu tempat. Tokohtokoh yang dimunculkan dalam cerita rakyat umumnya diwujudkan dalam bentuk binatang, manusia dan dewa. Cerita berasal dari kata biblion dan therapeia. Biblion berarti buku atau bahan cerita, sementara therapeia artinya penyembuhaan. Jadi, Teknik cerita dapat dimaknai sebagai upaya penyembuhan melalui buku. Bahan cerita berfungsi untuk mengalihkan orientasi dan memberikan pandangan-pandangan yang positif sehingga menggugah kesadaran penderita untuk bangkit menata hidupnya. "Teknik cerita adalah istilah yang dilontarkan oleh Samuel Crothers untuk mendeskripsikan penggunaan buku sebagai bagian dari proses guru" Jackson (dalam Erford, 2016).

Austin (dalam Apriliawati, 2011: 30) menjelaskan bahwa "Teknik cerita untuk anak adalah menggunakan buku sebagai terapi untuk mendukung kebutuhan anak dalam memproses pengalaman pribadi yang sulit seperti pengalaman yang menyakitkan dan membingungkan bagi anak". Sedangkan McArdle \& Byrt (dalam Apriliawati, 2011: 30) menjelaskan bahwa "Teknik cerita didefinisikan sebagai terapi menggunakan buku untuk memfasilitasi pengungkapan diri, penerimaan diri dan aktualisasi diri seseorang". Mengembangkan rasa yang lebih positif dari diri mereka sendiri, belajar tentang dunia, mengatasi stres, memberikan wawasan terhadap suatu masalah, menegaskan pikiran dan perasaan, merangsang diskusi tentang masalah, Menciptakan kesadaran orang lain yang memiliki masalah yang sama, memberikan solusi untuk masalah, mengkomunikasikan nilai-nilai dan sikap baru, dan menemukan makna dalam 
kehidupan, Mendorong anak gemar membaca, ketika anak-anak membaca buku cerita, mereka dapat mengaitkan masalah mereka dengan karakter yang ada di buku, dan belajar bahwa mereka tidak sendirian atau orang pertama yang mengalami masalah itu, Mendampingi seseorang yang tengah mengalami emosional yang berkecamuk karena permasalahan yang dihadapi dengan menyediakan bahan- bahan cerita dengan topik yang tepat dan mengandung nilainilai karakter yang ingin dibangun pada diri individu yang bersangkutan, Menyajikan informasi yang dibutuhkan atau sesuai dengan nilai karakter yang ingin mereka bangun, Membentuk tingkah lakunya secara umum, dengan mêngetahui informasi yang ada dalam bahan cerita, mereka dapat secara khusus membentuk sikap, persepsi, mengubah prasangka sosial dan perubahan Iainnya, Sebagai stimulasi pikiran yang memungkinkan para anggota dapat menyilangkan gagasan-gagasan sehingga kesadarannya menjadi meningkat.

Teknik cerita menggunakan bahan cerita yang mengandung nilai-nilai karakter yang ingin dibangun, menyajikan informasi yang dibutuhkan, mengungkapkan masalah yang dihadapinya, dan membantu anak agar mampu menemukan solusi yang dihadapinya didalam dalam bukuceritaPurwanto (dalam Emen, 2016: 12) menjelaskan bawha intervensi cerita dapat dikelompokkan dalam empat aspek, yaitu: (1) Aspek intelektual, (2) Aspek sosial, (3) Aspek perilaku individu, dan (4) Aspek emosional. Adapun penjelasannya sebagai berikut: Aspek intelektual, Pada aspek intelektual individu memperoleh pengetahuan tentang perilaku yang dapat memecahkan masalah, membantu pengertian diri, serta mendapatkan wawasan intelektual. Selanjutnya, individu dapat menyadari ada banyak pilihan dalam menangai masalah, Aspek social, Di tingkat sosial, individu dapat mengasah kepekaan sosialnya. Ia dapat melampaui bingkai referensinya sendiri melalui imajinasi orang lain. Teknik ini dapat menguatkan pola-pola sosial, budaya, menyerap nilai kemanusiaan dan saling memiliki. Aspek perilaku individuPerilaku individu akan mendapatkan kepercayaan diri untuk membicarakan masalah-masalah yang sulit didiskusikan akibat perasaan takut, malu, dan bersalah. Lewat membaca, individu didorong untuk diskusi tanpa rasa malu akibat rahasia pribadinya terbongkar. Aspek emosional Pada tingkat emosional, individu dapat terbawa perasaannya dan mengembangkan kesadaran menyangkut wawasan emosional. Teknik ini dapat menyediakan solusi-solusi terbaik dari rujukan masalah sejenis yang telah dialami orang lain sehingga merangsang kemauan yang kuat pada individu untuk memecahkan masalahnya.

Pembahasan tentang tahap-tahap dalam mengimplementasikan Teknik cerita sangat penting, terutama bagi guru. Dengan mengetahui dan menguasai apa yang sebenarnya terjadi dan apa yang hendaknya terjadi didalam proses Teknik cerita, guru akan mampu menyelenggarakan kegiatan dengan baik. Abdullah (dalam Erford, 2016) menjelaskan bahwa dalam mengimplementasikan Teknik cerita terdapat empat tahap yaitu: Perlu bagi guru profesional untuk mengidentifikasi kebutuhan-kebutuhan anak, Guruprofesional perlu memilih bukubuku yang cocok untuk situasi anak. Buku tersebut perlu ditulis di tingkat yang akan dapat dipahami anak, dan tokoh-tokoh dalam ceritanya perlu dapat dipercaya, Dalam tahap presentasi, anak membaca buku-buku, biasanya secara mandiri, di luar waktu sesi, dan selama sesi-sesi guru ia mendiskusikan aspekaspek penting buku tersebut bersama 
guru, dan Pada tahap terakhir biblioterpi, yaitu tahap tindak lanjut, guru profesional dan anak mendiskusikan apa yang telah anak pelajari maupun apa yang telah dicapai dari mengidentifikasikan diri dengan tokoh cerita.

Berbicara mengenai tahap-tahap Teknik cerita, Suparyo dan McIntyre (dalam Apriliawati, 2011: 34) menjelaskan bahwacerita terdiri dari tiga tahapan yaitu: (1) identifikasi, (2) katartis), dan (3) wawasan mendalam (insight). Adapun penjelasannya sebagai berikut: Identifikasi, Anak mengidentifikasi dirinya dengan karakter dan peristiwa yang ada dalam buku, baik yang bersifat nyata maupun fiktif. Bila bahan cerita yang disarankan tepat, maka anakakan mendapatkan karakter yang mirip atau mengalami peristiwa yang sama dengan dirinya. Digunakan buku yang sesuai dengan tahapan perkembangan usia anak dan mirip dengan situasi yang dialami anak. Karakteristik, Pertama-tama pembaca mengikuti tantangan atau masalah karakter, dan kemudian membaca bagaimana situasi ini diselesaikan. Setelah situasi teratasi, pengalaman rasa lega terjadi. Anak menjadi terlibat secara emosional dalam kisah dan menyalurkan emosi yang terpendam dalam dirinya (melalui diskusi atau karya seni). Selain itu, pembaca juga dapat mengidentifikasi dirinya dengan emosi karakter.Akibatnya, para pembaca menunjukkan emosi mereka dalam tahap ini. Selain diikuti dengan diskusi, memungkinkan bagi anak yang sulit mengungkapkan perasaannya secara verbal menggunakan cara lain yaitu melalui tulisan, mewarnai, menggambar, drama dengan menggunakan boneka atau bermain peran. Wawasan mendalam (insight), Anak menyadari bahwa masalah yang mereka hadapi bisa diselesaikan.
Permasalahan anak mungkin saja ditemukan dalam karakter tokoh dalam buku sehingga dalam menyelesaikan masalah dengan mempertimbangkan langkah-langkah yang ada dalam cerita. Aplikasi bibliotherapy dilakukan dengan cara: (a) Mengidentifikasi kebutuhan anak yang dilakukan melalui pengamatan, (b) Menyesuaikan kebutuhan anak dengan bahan cerita yang tepat, (c) Memutuskan susunan waktu, sesi, serta bagaimana sesi diperkenalkan pada anak, (d) Merancang aktivitas tindak lanjut setelah membaca seperti diskusi, menulis, menggambar atau drama, (e) Memberi jedawaktu beberapa menit agar anak dapat merefleksikan materi ceritanya, dan (f) Mendampingi anak mengakhiri terapi melalui diskusi dan menyusun daftar jalan keluar yang mungkin atau aktivitas lainnya.

\section{METODE PENELITIAN}

Metode penelitian ini adalah; kerangka yang di buat oleh peneliti sebagai rencana sebuah penelitian yang di gunakan untuk memperoleh kebenaran. Metode pendekatan atau jenis penelitian ini yaitu pengaruh dengan metode kuantitatif. Manfaat dari rancangan penelitian adalah untuk menggambarkan skema penelitian. Rangcangan penelitian adalah suatu pendekatan yang digunakan dalam suatu penelitian. Dalam metodelogi penelitian dijelaskan bahwa: Rancangan pada dasarnya merupakan keseluruhan proses pemikiran dan penentuan matang tentang hal-hal yang dilakukan serta dapat pula dijadikan dasar-dasar penelitian baik oleh peneliti sendiri maupun orang lain terhadap penelitian dan bertujuan memberi pertanggung jawaban terhadap semua langkah yang diambil" (Sugiyono, 2010).

Kaitannya dengan penelitian ini, yang menjadi populasi adalah seluruh anakUsia 5-6 tahun berjumlah 20 peserta 
didik. Dalam suatu penelitian, peneliti harus mampu menentukan populasi dan sampel untuk mengetahui batasan penelitian yang dilakukan berhubung dengan wilayah sumber data yang dijadikan sebagai subyek penelitian."Sampel adalah sebagian atau wakil populasi yang diteliti.Dinamakan penelitian sampel apabila kita bermaksud untuk menggeneralisasikan hasil penelitian sampel" (Suharsimi, 2014), dan pendapat Sugiyono "sampel adalah sebagian dari jumlah dan karakteristik yang dimiliki oleh populasi tersebut. Bila populasi besar, dan peneliti tidak mungkin mempelajari semua yang ada pada populasi, misalnya karena keterbatasan dana, tenaga dan waktu, maka peneliti dapat menggunakan sampel yang diambil dari populasi itu" (Sugiyono, 2013).

Instrumen merupakan alat yang digunakan untuk memperoleh data tentang objek yang diteliti. "Instrument penelitian mencakup unsur-unsur yang dibutuhkan dalam pengumpulan data.Alat yang digunakan untuk memperoleh data dalam mengukur masing-masing variabel penelitian" (IKIP Mataram, 2011). Sedangkan ahli lain menjelaskan Instrumen penelitian adalah suatu alat yang digunakan untuk mengukur fenomena alam maupun sosial yang diamati” (Sugiyono, 2015). Di dalam pelaksanaan penelitian dimulai dengan menyusun instrumen penelitian yaitu alat untuk memperoleh data yang diinginkan. Dalam penelitian ini akan menggunakan pedoman observasi dan pengamatan anak yang sesuai dengan judul penelitian ini sebagai instrumen penelitian.

Dalam penelitian ini, instrumen yang digunakan adalah berupa pedoman tentang teknik cerita dan kemandirian, yaitu untuk memperoleh data tentang kemandirian, sedangkan observasi, dokumentasi sebagai metode pelengkap.
Dalam memperoleh data yang dibutuhkan, perlu teknik atau metode pengumpulan data, sehingga data yang diperoleh dapat dipertanggungjawabkan secara ilmiah. Teknik pengumpulan data yang dipergunakan dalam penelitian ini adalah teknik dokumentasi, observasi, dan wawancara. Data yang dikumpulkan memalui instrument peneliti selanjutnya Tehnik analisis data digunakan dalam penelitian ini adalah pengujian hipotesis nihil yang diuji, yaitu tidak ada pengaruh teknik cerita terhadap sikap kemandirian anak usia 5-6 tahun. Pengujian hipotesis yang digunakan adalah t-test, yang mana apabila jumlah sampel berkolerasi atau berpasangan, misalnya membandingkan sebelum dan sesudah treatmen atau perlakuan maka digunakan rumus t test.

\section{HASIL PENELITIAN DAN \\ PEMBAHASAN}

Setelah mendapatkan data tentang jumlah subjek selama penelitian ini, maka langkah sealanjutnya adalah melakukan obsevasi kepada seluruh subjek yang berjumlah 20 anak. Dari hasil observasi pre-test ini peneliti dapat mengkatagorikan tingkatan skor berdasarkan kelas interval. Dimana tingakatan tertinggi diberikan treatmen teknik biblioterapi untuk dapat meningkatkan sikap kemandirian pada saat pengisian post-test. Untuk kepentingan perhitungan analisis statistik, maka hipotesis alternative (Ha) yang mengatakan: Ada Pengaruh Teknik Cerita Terhadap Sikap Kemandirian Pada Anak Usia 5-6 Tahun. Maka perlu diubah terlebih dahulu kedalam hipotesis nihil (Ho) yang mengatakan: Tidak Ada Pengaruh Teknik Cerita Terhadap Sikap Kemandirian Pada Anak Usia 5-6 Tahun. Dalam penelitian ini, pengumpulan data dilakukan beberapa kali yaitu sebelum dan sesudah pengamatan dilakukan. Karena dalam penelitian ini menggunakan pengamatan. Bahwa 
pelaksanaan teknik cerita mempunyai peranan yang positif dalam membantu sikap kemandirian anak. Kemandirian biasanya ditandai dengan tingkah laku, dan penilaian dari guru.

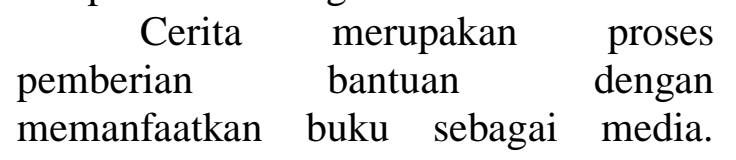
Metode terapi ini sangat dianjurkan terutama bagi penderita yang sulit mengungkapkan permasalahannya secara verbal. Buku merupakan media yang tepat untuk mendapatkan wawasan, pengetahuan, informasi, dan hiburan. Selain itu, buku dapat menjadi media terapi atau penyembuhan bagi penderita gangguan mental, seperti gangguan kecemasan, trauma, dan stres. Sehubungan dengan metode terapi ini guru atau guru dapat bersikap penuh simpati dan empati. Dengan cara ini masalah yang dihadapi konseli dapat berkurang. Karena dengan sikap ini, ia akan memberikan kepercayaan kepada guru atau guru.

Melalui Teknik cerita memanglah sebuah sarana yang tepat dilakukan membantu memecahkan permasalahan yang menggunakan media bahan cerita untuk mengatasi permasalahan yang dihadapi oleh seseorang yang bermasalah. Dengan demikian Teknik cerita diharapkananak mempunyai sikap kemandirian yang tinggi sehingga dapat mencapai hasil yang memuaskan serta mampu menyadari kelebihan serta kekurangan yang dimiliki. Berdasarkan dengan hal tersebut, maka peneliti dapat mengambil kesimpulan bahwa apabila Teknik ceritamampu diterapkan kepada anak maka akan membantu guru dalam memecahkan masalah terutama masalah sikap kemandirian. Artinya apabila Teknik cerita dilakukan secara maksimal, maka sikap kemandirian anak akan meningkat, sehingga anak lebih mandiri dalam menentukkan masa depannya.

Cerita adalah salah satu teknik baik yang memanfaatkan media buku atau sejenisnya di dalam bacaan untuk membantu dalam mengubah pikiran, perasaan, perilaku dengan menemukan kesenangan dalam membaca sehingga dapat memotivasi anak agar mampu lebih mandiri lagi dalam belajar. Pelaksanaan teknik cerita sangat berguna bagi peningkatan sikap anak untuk membentuk menjadi pribadi yang mandiri karena anak lebih paham tentang hal-hal yang memang seharusnya dilakukan secara mandiri, tetapi karena lingkungan yang selalu bersifat sudah menyediakan, jadi seorang anak terkadang kurang mau untuk berusaha sendiri.Dengan pelaksanaan teknik cerita ini diharapkan anak selalu termotivasi untuk belajar, mengubah anak menjadi lebih baik, anak mempunyai pengetahuan baru dan anak berkeinginan lebih baik darisebelumnya.

Sikap kemandirian merupakan suatu usaha yang dilakukan untuk mengedalikan emosi untuk melakukan aktivitas belajar dengan cara melatih diri sendiri tanpa bergantung pada orang lain untuk memperoleh perubahan tingkah laku yang mempunyai kebebasan dalam membuat keputusan serta mampu bertanggung jawab atas tindakannya, sebagai hasil pengalamannya sendiri dalam interaksi denganlingkungannya. Teknik cerita memiliki peran untuk membantu anak agar dapat menemukan kelemahan serta kelebihan yang belum dikenali dalam dirinya dengan menggunakan media cerita yang sesuai dengan kebutuhannya sehingga dapat mengatasi masalah yang berkaitan dengan sikap kemandirian nya.

Teknik cerita di sini menggunakan teknik bibliotherapiatau terapi cerita. adapun cerita yang digunakan adalah cerita rakyat atau cerita lokal yang mengandung isi yang dapat menjadikan anak menjadi lebih mandiri dalam belajarnya teknik cerita ini juga 
harapannya setelah dibacakannya cerita tersebut, anak yang sebelumnya mempunyai kemandirian yang rendah, akan menjadi meningkat. Jadi, teori yang telah diajukan dalam pembahasan yang selanjutnya dibandingkan dengan hasil analisi yang diperoleh ternyata Hipotesis Nihil (Ho) di tolak yang mengatakan: Tidak Ada Pengaruh Teknik Cerita Terhadap Sikap Kemandirian Pada Anak Usia 5-6 Tahun. Dan Hipotesis Alternatif (Ha) yang di terima mengatakan: Ada Pengaruh Teknik Cerita Terhadap Sikap Kemandirian Anak Usia 5-6 Tahun.

\section{SIMPULAN DAN SARAN}

Dari hasil analisis data bahwa t-hitung yang diperoleh adalah sebesar 6,678 sedangkan nilai t-tabel dengan taraf signifikan $0,5 \%=\mathrm{N}-1=(15-1)=14$ adalah 2,145 kenyataan ini menunjukkan nilai t-tes yang diperoleh dalam penelitian ini adalah lebih besar daripada nilai t-tabel $(6,678 \geq 2,145)$ berarti signifikan, maka kesimpulan dalam penelitian ini adalah: Ada pengaruh teknik cerita terhadap sikap kemandirian anak usia 5-6 Tahun.

Berdasarkan simpulan di atas, peneliti sarankan: Bagi kepala sekolah, hasil penelitian diharapkan agar informasi yang diperoleh dalam penelitian ini dapat berguna bagi kepala sekolah untuk mendorong Guru dalam memanfaatkan teknik cerita untuk membantu sikap kemandirian pada anak. Bagi guru, hasil penelitian ini diharapkan sebagai masukan untuk lebih meningkatkan profesionalisme di dalam memberikan layanan bagi para anak berkaitan dengan memberikan teknik cerita untuk membantu anak agar meningkatkan sikap kemandirian. Bagi peneliti lain, hasil penelitian ini diharapkan sebagai bahan kajian bagi peneliti selanjutnya yang berhubungan dengan penelitian ini, sehingga hasilnya akan lebih luas dan mendalam yang belum terungkap dalam penelitian ini.

\section{DAFTAR PUSTAKA}

Aisyah, Siti dkk. 2007. Perkembangan dan Konsep Dasar Pengembangan Anak Usia Dini. Jakarta: Universitas Terbuka.

Ali \& Asrori. 2011. Psikologi Remaja (Perkembangan Peserta Didik). Jakarta: PT. Bumi Aksa.

Aluh Hartati, Hariadi Ahmad dan Andika Rifzar Mandasingi. 2020. Hubungan antara Pengendalian Diri dengan Prestasi Siswa SMKN 1 Sumbawa Besar. Realita Jurnal Bimbingan dan Konseling Vol. 5 No 2 Edisi Oktober 2020. Hal 1051 - 1066. Prodi Bimbingan dan Konseling Fakultas Ilmu Pendidikan dan Psikologi Universitas Pendidikan Mandalika.

Budiningsih, Asri. 2012. Belajar Dan Pembelajaran. Jakarta: Rineka Cipta

Departemen Pendidikan Nasional, 2003.Undang-Undang Nomor 20 Tahun 2003, Tentang System Pendidikan Nasional, Jakarta: Depdiknas.

Desmita. 2016. Psikologi Perkembangan Peserta Didik. Bandung: PT Remaja Rosdakarya Eliasa, Eva Imania, 2007. Biblioterapi Sebagai Sebuah Metode Tindakan yang Bermakna.Laporan Hasil Penelitian.Yokyakarta: FIP UNY

Direktorat Pendidikan Usia Dini. 2004. Modul Sosialisasi PAUD: Konsep Dasar Pendidikan Anak Usia Dini. Proyek Pengembangan Anak Usia Dini Pusat

Erford, B.T, (2016). 40 Teknik Yang Harus Diketahui Setiap Konselor (Edisi ke-2). 
Yogyakarta: Pustaka Belajar.

Hariadi Ahmad dan Aluh Hartati. 2016. Panduan Pelatihan Self Advocacy Siswa SMP untuk Konselor Sekolah. LPP Mandala. Mataram

Hariadi Ahmad dan Aluh Hartati. 2016.

Penerapan Teknik Structure Learning Approach dalam Meningkatkan Self Advocacy Mahasiswa Prodi BK IKIP Mataram. Realita Jurnal Bimbingan dan Konseling Vol. 1 No 2 Edisi Oktober 2016. Hal 117 - 127. Prodi Bimbingan dan Konseling Fakultas Ilmu Pendidikan IKIP Mataram

Hariadi Ahmad dan Dini Kurnia. 2017. Pengaruh Teknik Biblio Edukasi Terhadap Rasa Rendah Diri Pada Siswa Kelas XI di SMA Negeri 8 Mataram. Realita Jurnal Bimbingan dan Konseling Vol. 2 No 1 Edisi April 2017. Hal 194 - 202. Prodi Bimbingan dan Konseling Fakultas Ilmu Pendidikan IKIP Mataram

Hariadi Ahmad, Ahmad Zainul Irfan dan Dedi Ahlufahmi. 2020. Hubungan antara Pola Asuh Orang Tua dengan Penyesuaian Diri Siswa. Realita Jurnal Bimbingan dan Konseling Vol. 5 No 1 Edisi April 2020. Hal 950 - 966. Prodi Bimbingan dan Konseling Fakultas Ilmu Pendidikan dan Psikologi Universitas Pendidikan Mandalika.

Hariadi Ahmad, Aluh Hartati dan Jessica Festy Maharani. 2020. Pengaruh Dukungan Psikologis Awal pada Remaja dalam Pencegahan Covid 19. Realita Jurnal Bimbingan dan Konseling Vol. 5 No 2 Edisi Oktober 2020. Hal 1091 - 1106. Prodi Bimbingan dan Konseling Fakultas Ilmu Pendidikan dan Psikologi Universitas Pendidikan Mandalika.

Hariadi Ahmad, Aluh Hartati, dan Nuraeni. 2018. Penerapan Teknik Structure Learning Approach (SLA) dalam Meningkatkan Kesadaran Empati Diri Siswa Madrasah Aliyah Al Badriyah. Realita Jurnal Bimbingan dan Konseling Vol. 3 No 2 Edisi Oktober 2018. Hal $600-605$ Prodi Bimbingan dan Konseling Fakultas Ilmu Pendidikan IKIP Mataram.

Hariadi Ahmad, dan Lalu Andry Adifa Maulana. 2019. Pengaruh Teknik Video Edukasi Terhadap Berfikir Positif Siswa SMPN 16 Mataram. Realita Jurnal Bimbingan dan Konseling Vol. 4 No 1 Edisi April 2019. Hal 727 - 741. Prodi Bimbingan dan Konseling Fakultas Ilmu Pendidikan IKIP Mataram.

Hariadi Ahmad, dan Yolana Oktaviani. 2019. Pengaruh Teknik Self Instruction Terhadap Harga Diri Siswa Kelas Kelas XI di SMK Negeri 1 Lingsar Kabupaten Lombok Barat. Realita Jurnal Bimbingan dan Konseling Vol. 4 No 2 Edisi Oktober 2019. Hal $806-815$. Prodi Bimbingan dan Konseling Fakultas Ilmu Pendidikan IKIP Mataram.

Hariadi Ahmad, Lidya Wurru dan Jessica Festy Maharani. 2021. Hubungan antara Keharmonisan Keluarga dengan Perilaku Agresif pada Siswa Madrasah Aliyah Raudlatusshibyan NW Belencong. Realita Jurnal Bimbingan dan Konseling Vol. 6 No 1 Edisi April 2021. Hal 1205 - 1212. Prodi Bimbingan 
https://e-journal.undikma.ac.id/index.php/realita

dan Konseling Fakultas Ilmu Pendidikan dan Psikologi Universitas Pendidikan Mandalika.

Hariadi Ahmad, Mustakim dan Syafaruddin. 2018. Hubungan antara Penyesuaian Diri dengan Berfikir Positif Siswa Kelas VIII SMP Negeri Seteluk Kabupaten Sumbawa Barat. Realita Jurnal Bimbingan dan Konseling Vol. 3 No 1 Edisi April 2018. Hal 482 - 494. Prodi Bimbingan dan Konseling Fakultas Ilmu Pendidikan IKIP Mataram

Hasrul dan Hariadi Ahmad. 2021. Mereduksi Prasangka Etnik Siswa dengan Teknik Restructuing Cognitive Suatu Krangka Konseptual. Realita Jurnal Bimbingan dan Konseling Vol. 6 No 1 Edisi April 2021. Hal 1213 - 1222. Prodi Bimbingan dan Konseling Fakultas Ilmu Pendidikan dan Psikologi Universitas Pendidikan Mandalika.

IKIP Mataram, (2011). Pedoman Pembimbingan dan Penulisan Karya Ilmiah. Mataram.

Komsiyah, Indah. 2012. Belajar Dan Pembelajaran. Yogyakarta: Teras

Margono, (2007). Metodologi Penelitian Pendidikan. Jakarta: Rineka Cipta.

Margono, (Slamet). (1996). Filsafat danPrinsip-Prinsip Manajemen Mutu Terpadu di Perguruan Tinggi. Jakarta: Heds Projek.

Purwanto, Evanthe, Maret (2015). "Pengaruh Biblioterapi Terhadap Psychological wellbeing Perempuan Lajang”. Jurnal Mahasiswa Universitas Surabaya: Vol 4 No. 1.

Riduwan, (2016). Dasar-dasar statistika. Bandung: Alfabeta.
Shecman, (Eliasa). (2007). Biblio Therapy As A Method of Meaningful Treatment : ISSN 114 434-438 2007).

Sugiyono, (2016). Metode Penelitian Pendidikan, Pendekatan Kuantitatif, Kualitatif, dan R\&D Jakarta: Alfa Beta.

Sugiyono. 2010. Metode Penelitian Pendidikan (Pendekatan Kuantitatif, Kualitatif, dan $R \& D)$. Bandung: Alfabeta

Sugiyono. (2012). Metode Penelitian Pendidikan (Pendekatan Kuantitatif, Kualitatif, dan $R \& D)$. Bandung: Alfabeta.

Suharsimi, (2006). ProsedurPenelitian. Jakarta: PT Rineka Cipta.

Suharsimi, (2014). Prosedur Penelitian Suatu Pendekatan Praktik. Jakarta: Rineka Cipta. 


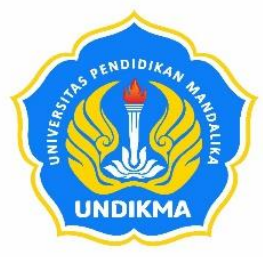

\section{UNIVERSITAS PENDIDIKAN MANDALIKA FAKULTAS ILMU PENDIDIKAN DAN PSIKOLOGI PROGRAM STUDI BIMBINGAN DAN KONSELING Jurnal Realita}

Gedung Dwitiya Lt.3. Jln Pemuda 59A Mataram-NTB 83125 Tlp (0370) 638991 e-mail: realita@undikma.ac.id; web: e-journal.undikma.ac.id

\section{PEDOMAN PENULISAN}

1. Naskah merupakan hasil penelitian, pengembangan atau kajian kepustakaan di bidang pendidikan, pengajaran, pembelajaran, bimbingan dan konseling, dan Psikologi

2. Naskah merupakan tulisan asli penulis dan belum pernah dipublikasikan sebelumnya dalam jurnal ilmiah lain,

3. Naskah dapat ditulis dalam Bahasa Indonesia atau Bahasa Inggris.

4. Penulisan naskah mengikuti ketentuan sebagai berikut:

$\begin{array}{llll}\text { Program } & \text { MS Word } & \text { Margin kiri } & 3.17 \mathrm{~cm} \\ \text { Font } & \text { Times New Roman } & \text { Margin kanan } & 3.17 \mathrm{~cm} \\ \text { Size } & 12 & \text { Margin atas } & 2.54 \mathrm{~cm} \\ \text { Spasi } & 1.0 & \text { Margin bawah } & 2.54 \mathrm{~cm} \\ \text { Ukuran kertas } & \text { A4 } & \text { Maksimum 20 halaman }\end{array}$

5. Naskah ditulis dengan sistematika sebagai berikut: Judul (huruf biasa dan dicetak tebal), nama-nama penulis (tanpa gelar akademis), instansi penulis (program studi, jurusan, universitas), email dan nomor telpon penulis, abstrak, kata kunci, pendahuluan (tanpa sub-judul), metode penelitian (tanpa sub-judul), hasil dan pembahasan, simpulan dan saran (tanpa sub-judul), dan daftar pustaka.

Judul secara ringkas dan jelas menggambarkan isi tulisan dan ditulis dalam huruf kapital. Keterangan tulisan berupa hasil penelitian dari sumber dana tertentu dapat dibuat dalam bentuk catatan kaki. Fotocopy halaman pengesahan laporan penelitian tersebut harus dilampirkan pada draf artikel.

Nama-nama penulis ditulis lengkap tanpa gelar akademis.

Alamat instansi penulis ditulis lengkap berupa nama sekolah atau program studi, nama jurusan dan nama perguruan tinggi. Penulis yang tidak berafiliasi pada sekolah atau perguruan tinggi dapat menyertakan alamat surat elektronik dan nomor telpon.

Abstrak ditulis dalam 2 (dua) bahasa: Bahasa Inggris dan Bahasa Indonesia. Naskah berbahasa Inggris didahului abstrak berbahasa Indonesia. Naskah berbahasa Indonesia didahului abstrak berbahasa Inggris. Panjang abstrak tidak lebih dari 200 kata. Jika diperlukan, tim redaksi dapat menyediakan bantuan penerjemahan abstrak kedalam bahasa Inggris.

Kata kunci (key words) dalam bahasa yang sesuai dengan bahasa yang dipergunakan dalam naskah tulisan dan berisi 3-5 kata yang benar-benar dipergunakan dalam naskah tulisan.

Daftar Pustaka ditulis dengan berpedoman pada Pedoman Penulisan Karya Ilmiah Universitas Pendidikan Mandalika. 


\begin{tabular}{|c|c|c|c|c|c|}
\hline & & & & \\
JURNAL & VOLUME & NOMOR & EDISI & HALAMAN & P ISSN : 2503 - 1708 \\
REALITA & 6 & 2 & Oktober 2021 & $1326-1430$ & E ISSN : 2722 - 7340 \\
& & & & \\
\hline
\end{tabular}

Alamat Qedaksi:

Program Studi Bimbingan dan Konseling Fakultas Ilmu Pendidikan dan Psikologi

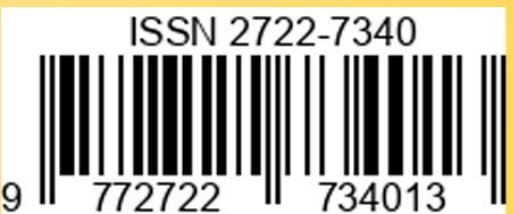

Universitas Pendidikan Mandalika

Gedung Dwitiya, Lt. 3 Jalan Pemuda No. 59A Mataram Telp. (0370) 638991

Email : realita@undikma.ac.id

Web : e-journal.undikma.ac.id

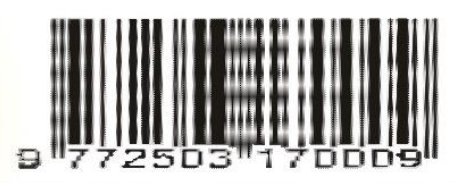

